\title{
NON-METRIC VARIATIONS OF THE AXIAL SKELETON BONES IN MEDIEVAL SKELETONS FROM VINICA FORTRESS (VINICHKO KALE)
}

\author{
Matveeva Niki ${ }^{1}$, Veljanovska Fanica ${ }^{2}$, Zhivadinovikj Julija ${ }^{1}$, Zafirova Biljana ${ }^{1}$, \\ Chadikovska Elizabeta ${ }^{1}$, Dodevski Ace ${ }^{1}$, Trpkovska Biljana ${ }^{1}$, Bojadzieva Stojanoska \\ Biljana $^{1}$
}

\author{
${ }^{1}$ Institute of Anatomy, Faculty of Medicine, Ss. Cyril and Methodius University in Skopje, \\ R. North Macedonia \\ ${ }^{2}$ Archeological Museum of R. North Macedonia, Skopje, R. North Macedonia \\ e-mail: niki.matveeva@medf.ukim.edu.mk
}

\begin{abstract}
The majority of researchers use cranial and infracranial non-metric traits as separate entities in their investigations of the past populations. We decided to focus our investigation on the axial skeleton non-metric traits, consisting of components such as cranial and vertebral column skeleton. The main goal of our study was to gain some insight into the expression of axial skeleton non-metric traits in a medieval population sample. We investigated 72 well preserved skeletons from the medieval period documented collection (11-12 century AD) in order to examine axial skeleton non-metric traits. The skeletons belonged to individuals aged 20 to 65 years, of both sexes, exhumed from the necropolis Vinichko Kale.

Analysis of cranial non-metric traits in our population sample showed a high prevalence of occipital bone cranial traits, such as os apicis (13.9\%) and torus occipitalis (20.8\%). Among vertebral column non-metric traits, a high prevalence of cervical spine traits, such as ponticulus posterior atlantis (11\%), foramen transversarium partitum - FTP $(33.3 \%)$, foramen transversarium apertum - FTA $(13.9 \%)$ and cervical ribs $(13.9 \%)$ was noted. Our findings of skeletal non-metric traits in the medieval population can provide additional knowledge in the skeletal growth and development in general.

Keywords: osteology, archeology, anatomical variations, axial skeleton

\section{Introduction}

Historical overview

Vinichko kale (Vinica Fortress) is a former settlement from the late-antique period, located above the city of Vinica, R. North Macedonia, on a hill of about 40 meters above sea level. There are many artefacts and samples that can be used to reconstruct the life in this antique settlement. The life in this area existed during an undoubtedly long period of time, since the early Stone Age (Neolithic period) to the mature medieval period. The majority of the testimonies found at this location belong to the late antique period. Numerous terra cotta reliefs, with iconographical representations, scenes from the Old and New Testament and illustrated psalms are still subject of interest of the scientific community.

Bone discrete traits are anatomical asymptomatic variations. Non-metric traits are believed to be the final points of genetically controlled development processes which are affected by environmental factors (Saunders, 1989). Although these anatomical variations are
\end{abstract}


rare, they are important for many disciplines such as biological anthropology, archeology, developmental anatomy, clinical and forensic medicine. The analysis of non-metric traits in anthropology remains an important approach in the assessment of genetic relationships among populations or in discovering the existence of parental structures within a community. The majority of authors have used cranial non-metric traits, in contrary to fewer researchers who have used infracranial traits in their investigations. Some authors [1] reported the potential of axial skeleton variants for addressing paleogenetic relationships. Saunders et al. [2,3] demonstrated low levels of intercorrelation among the infracranial skeleton traits. Edwards [4] found no significant correlations between six atlas variants using a sample from the Dakhleh Oasis. It is well-known that the development of the upper cervical vertebra is strongly related to the development of basiocciput and exocciput, thus from the point of view of developmental anatomy we decided to focus our investigation on cranial and vertebral non-metric traits as constituent components of the axial skeleton.

The primary purpose of our study was to provide information about the expression of axial skeleton non-metric traits (cranial and vertebral) in a sample of medieval population and their association with sex, laterality and age.The secondary purpose was to enrich the knowledge about the skeleton growth and development in general.

\section{Material and Methods \\ Sample}

The archeological site of Vinica fortress (Vinichko kale) was recorded for the first time in 1953. The necropolis comprises more than a hundred graves around a church in a shape of inscribed cross dating from the 11th and 12th century AD, according to the main researcher of the team [5]. Since 1985 there have been few campaigns of systematic archeological excavations (1985-2001).

During these excavations 102 skeletons have been exhumed and examined [6]. Our study sample comprised 72 well preserved skeletons from the documented collection belonging to individuals aged 20 to 65 years (Figure 1). Since most of the skeleton elements were present, age and sex estimates were performed with reasonable accuracy using standard anthropological techniques [7]. Figure 2 presents the demographic composition of our medieval population sample.

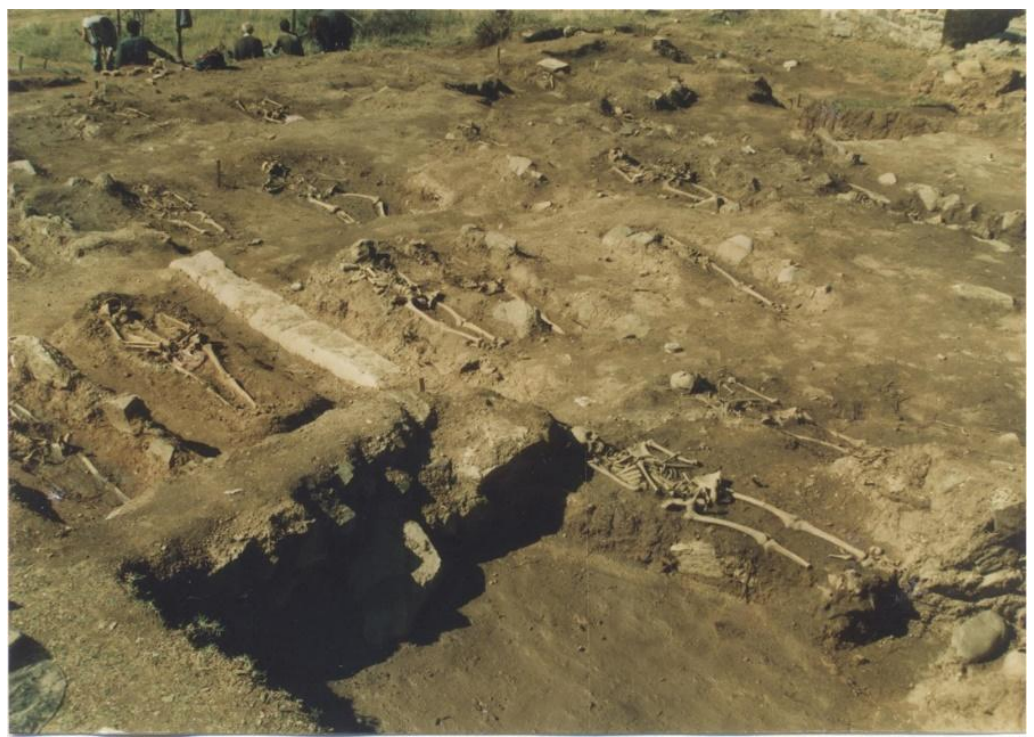

Fig. 1. The necropolis of Vinica fortress (Vinichko kale) 


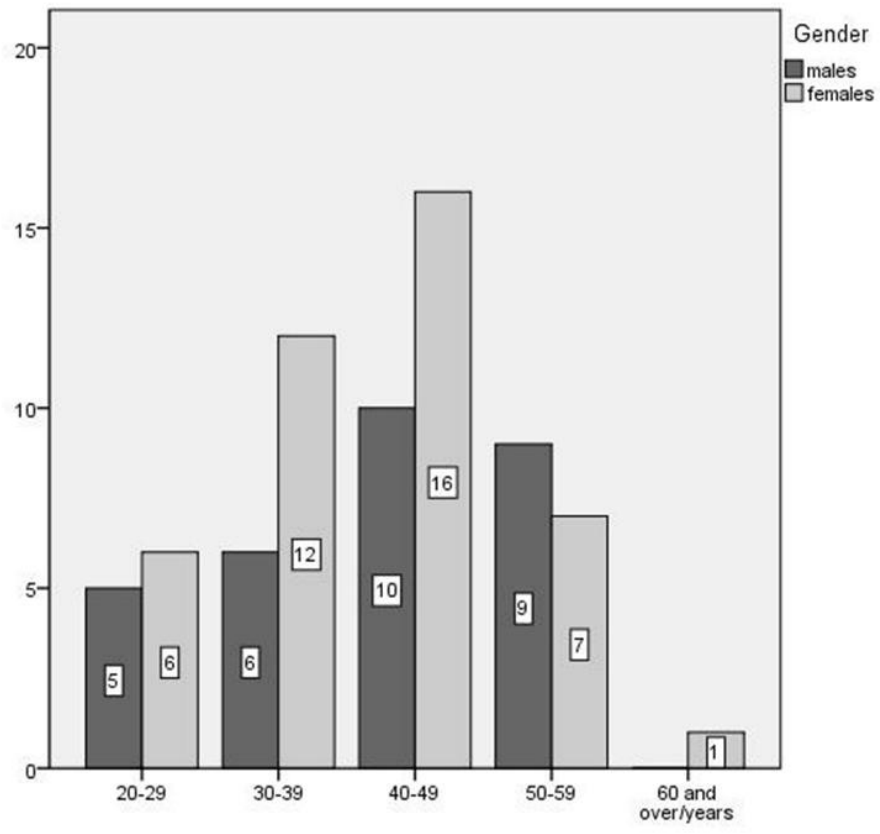

Fig. 2. Age and sex distribution of the medieval population sample from Vinica fortress (Vinichko kale)

\section{Methods}

Two axial skeleton components were examined separately, craniofacial and vertebral column bones. Initially we selected and scored non-metric traits that were to be examined in our sample. Each bone was carefully macroscopically observed by two observers and after mutual consent, each variant was noted in terms of presence or absence. Traits that occurred unilaterally were scored on each side separately, to record the side dimorphism.

Non-metric traits selected for the craniofacial bones were chosen from established standards [7] as follows: lambdoid, coronal and sagittal suture ossicles, parietal notch and occipitomastoid ossicles, as well as epipteric, asterionic and bregmatic bones. Skulls were observed for the presence of torus occipitalis (an elevated area between the supreme and superior nuchal line) and distinct supreme nuchal line. Remnants of transverse occipital or frontal suture were examined in order to identify sutura mendosa or sutura metopica. Variations in the squamous part of the occipital bone, i.e. the presence of interparietal bone and preinterparietal bone was carefully examined. The differentiation of interparietal and preinterparietal bone was done in line with the summarised criteria described by different authors $[8,9]$. Interparietal bone or os inca was identified as a bone located slightly above the external occipital protuberance with lower border at the highest nuchal line, i.e. on the demarcation line between the primary and secondary centers, which corresponds to the transverse occipital suture, also known as the lateral fissure, lateral notch or sutura mendosa. Preinterparietal bone or os apicis was identified as a single bone or a group of bones, forming a triangular protrusion in the posterior part of the sagittal suture between the two parietal bones with lower borders located higher than the midline between the lambda and the highest nuchal line. Basoocciput and exocciput non-metric traits like condylus occipitalis bipartita were also examined. Facial bones were observed for the presence of traits characterized with hyperostosis or excess osseus growth such as torus palatinus, torus maxillaris and torus mandibularis.

Cervical segment of the vertebral column was examined for the presence of numerous non-metric traits. Variations of the atlas were observed, such as facies artcularis atlantis bipartita; ponticulus posterior (partial spur or bone bridge that arches over the sulcus of the vertebral artery behind the superior articular facet) and ponticulus lateralis (partial spur or bone bridge 
from the superior facet or the lateral mass to the posterior root of the transverse process) [10]. Anatomical variants of foramen transversarium (FT) were observed, such as foramen transversarium apertum (FTA), a result of anterior bony bar (costal element) absence and foramen transversarium partitum (FTP), foramen split by bony spicle into two, rarely three foramens. Transitional vertebrae that occur at the cervicothoracic, thoracolumbar or lumbosacral junction, such as cervical, lumbar ribs, sacralization and lumbarization were observed and analyzed in our study as well. The whole spine was examined for the presence of block vertebra or hemivertebra, products of a failure of vertebral segmentation or formation. Spondylolysis was observed as osseous defect of pars interarticularis that create unilateral or bilateral cleft within the neural arch. The whole spine and sacrum was carefully examined for eventual presence of spina bifida, an outcome of incomplete dorsal midline closure of the osseus tissues during the fusion of the neural arch.

\section{Statistical analysis}

The prevalence of each non-metric trait in our sample was calculated according to sex, laterality and age. Chi-square test was used for testing significant associations with sex, laterality (unilateral $v s$ bilateral) and age. If the conditions of chi-square were not met, Fischer's exact test was used. Statistical analyses were made by using the SPSS (version 19) software (Chicago, Illinois, USA) with a threshold level of significance of 5\%.

\section{Results}

\section{Craniofacial non-metric traits}

Table1 presents the prevalence of the evaluated craniofacial non-metric traits in our sample. Ossa suturarum (Wormian bones) usually small, irregularly shaped ossicles, were found in most of the skulls sutures with variable prevalence. The most numerous were ossicula suturae lambdoidae with a prevalence of 55.6\% (40 individuals) and parietal noch ossicles with a prevalence of $12.5 \%$ (9 individuals). The prevalence of sutural bones in sagittal, coronal and occipitomastoid suture was 5.6\% (4 individuals), 4.2\% (3 individuals) and 2.8\% ( 2 individuals), respectively. Os epiptericum was found in 7 cases (bipartite in one case) with a prevalence of $9.7 \%$, and os asterii in 5 (bipartite in one case) with a prevalence of $6.9 \%$. Ossiculum bregmaticum was identified in one man aged 50-55 years as an associated trait with os apicis, torus occipitalis and bilateral os asterii. No significant difference was found in Wormian bones according to sex, age and laterality, except for parietal notch and occipitomastoid ossicles that were more frequently observed unilaterally (Table 2). However, most of the traits were age-stable because our sample comprised postadolescent individuals, although less Wormian bones were found in individuals aged over 50 years, with evident age-related obliteration for ossicula incisurae parietalis (Table 3).

Preinterparietal bone or os apicis was observed in 10 individuals (13.9\%) and os interparietale or os incae in $2(2.8 \%)$. In both cases os incae laterale dextrum was found (Figure 3). Single preinterparietal bone was observed in 6, multipartite in 3 and bipartite in one case. Sutura mendosa was encountered in 4 (5.6\%) and sutura metopica in two individuals $(2.8 \%)$. The incidence of torus occipitalis was significantly higher in males, torus occipitalis was observed in $15 / 20.8 \%$ males compared to $4 / 9.5 \%$ females. Distinct supreme nuchal line was found in 7 individuals $(9.7 \%)$. Partly divided condylus occipitalis by ridge was encountered in 2 individuals. In a female aged 30-35 years right bipartite condylus occipitalis was found as an associated trait with right costa cervicalis. No significant differences according to sex, age and laterality was found for these traits, except for torus occipitalis; the only hyperostotic cranial trait significantly more frequently observed in males. Among facial bones traits torus palatinus was most frequently observed with a prevalence of $15.3 \%$ (11 individuals). All individuals presenting with torus maxillaris were 20 to 29 years old (Table 2 and 3). 
Table 1. Number and prevalence of craniofacial non-metric traits according to gender in the medieval population sample from Vinichko kale necropolis

\begin{tabular}{|c|c|c|c|c|c|c|c|}
\hline \multirow{2}{*}{$\begin{array}{c}\text { Craniofacial non-metric } \\
\text { traits }\end{array}$} & \multicolumn{2}{|c|}{ Total } & \multicolumn{2}{|c|}{ Males } & \multicolumn{2}{|c|}{ Females } & \multirow{2}{*}{$p$ value } \\
\hline & $\mathbf{N}$ & $\%$ & $\mathbf{N}$ & $\%$ & $\mathbf{N}$ & $\%$ & \\
\hline Ossicula suturae lambdoideae & 40 & 55.6 & 19 & 63.3 & 21 & 50 & .378 \\
\hline Ossicula suturae coronalis & 3 & 4.2 & 1 & 3.3 & 2 & 4.8 & 1.00 \\
\hline Ossicula suturae sagittalis & 4 & 5.6 & 3 & 10 & 1 & 2.4 & .301 \\
\hline Ossiculua incisurae parietalis & 9 & 12.5 & 3 & 10 & 6 & 14.3 & .857 \\
\hline Ossiculum occipitomastoideum & 2 & 2.8 & 2 & 6.7 & & & .170 \\
\hline Os apicis & 10 & 13.9 & 5 & 16.7 & 5 & 11.9 & .818 \\
\hline Os epiptericum & 7 & 9.7 & 4 & 13.3 & 3 & 7.1 & .440 \\
\hline Os asterii & 5 & 6.9 & 4 & 13.3 & 1 & 2.4 & .153 \\
\hline Os incae & 2 & 2.8 & 1 & 3.3 & 1 & 2.4 & 1.00 \\
\hline Os bregmaticum & 1 & 1.4 & 1 & 3.3 & & & .417 \\
\hline Sutura metopica & 2 & 2.8 & 1 & 3.3 & 1 & 2.4 & 1.00 \\
\hline Sutura mendosa & 4 & 5.6 & 1 & 3.3 & 3 & 7.1 & .636 \\
\hline Torus occipitalis & 15 & 20.8 & 11 & 36.7 & 4 & 9.5 & $.012 *$ \\
\hline Linea nuchae suprema & 7 & 9.7 & 4 & 13.3 & 3 & 7.1 & .440 \\
\hline Condylus occipitalis partita & 2 & 2.8 & 1 & 3.3 & 1 & 2.4 & 1.00 \\
\hline Torus palatinus & 11 & 15.3 & 2 & 6.7 & 9 & 21.4 & .063 \\
\hline Torus maxillaris & 2 & 2.8 & 1 & 3.3 & 1 & 2.4 & 1.00 \\
\hline Torus mandibularis & 3 & 4.2 & 3 & 10 & & & .068 \\
\hline
\end{tabular}

$\mathrm{N}$, number of individuals; *, p<.05

Table 2. Number and prevalence of cranial non-metric traits according to laterality in the medieval population sample from Vinichko kale necropolis

\begin{tabular}{|c|c|c|c|c|c|c|c|c|c|}
\hline \multirow{2}{*}{ Craniofacial traits } & \multicolumn{2}{|c|}{$\begin{array}{c}\text { Left } \\
\text { unilateral }\end{array}$} & \multicolumn{2}{|c|}{$\begin{array}{c}\text { Right } \\
\text { unilateral }\end{array}$} & \multicolumn{2}{|c|}{ Unilateral } & \multicolumn{2}{|c|}{ Bilateral } & \multirow{2}{*}{$p$ value } \\
\hline & $\mathbf{N}$ & $\%$ & $\mathbf{N}$ & $\%$ & $\mathbf{N}$ & $\%$ & $\mathbf{N}$ & $\%$ & \\
\hline Ossicula incisurae parietalis & 5 & 6.9 & 2 & 2.8 & 7 & 9.7 & 2 & 2.8 & .096 \\
\hline Ossicula occipitomastoidea & & & 2 & 2.8 & 2 & 2.8 & & & \\
\hline Os epiptericum & 4 & 5.6 & 1 & 1.4 & 5 & 6.9 & 2 & 2.8 & .257 \\
\hline Os asterii & 3 & 4.2 & & & 3 & 4.2 & 2 & 2.8 & .655 \\
\hline Sutura mendosa & 2 & 2.8 & & & 2 & 2.8 & 2 & 2.8 & 1.00 \\
\hline Condylus occipitalis partita & & & 2 & 2.8 & 2 & 2.8 & & & \\
\hline
\end{tabular}

$\mathrm{N}$, number of individuals; $*, \mathrm{p}<.05$

Table 3. Number and prevalence of craniofacial non-metric traits according to age in the medieval population sample from Vinichko kale necropolis

\begin{tabular}{|c|c|c|c|c|c|c|c|c|c|c|c|}
\hline \multirow{2}{*}{ Craniofacial traits } & \multicolumn{2}{|c|}{$20-29 y$} & \multicolumn{2}{|c|}{$30-39 y$} & \multicolumn{2}{|c|}{$40-49 y$} & \multicolumn{2}{|c|}{$50-59 y$} & \multicolumn{2}{|c|}{$60-69 y$} & \multirow{2}{*}{ p value } \\
\hline & $\mathbf{N}$ & $\%$ & $\mathbf{N}$ & $\%$ & $\mathbf{N}$ & $\%$ & $\mathbf{N}$ & $\%$ & $\mathbf{N}$ & $\%$ & \\
\hline Ossicula suturae lambdoideae & 6 & 8.3 & 11 & 15.3 & 15 & 20.8 & 5 & 6.9 & & & .309 \\
\hline Ossicula suturae coronalis & & & 2 & 2.8 & 1 & 1.4 & & & & & .639 \\
\hline Ossicula suturae sagittalis & & & & & 2 & 2.8 & 2 & 2.8 & & & .629 \\
\hline Ossicula incisurae parietalis & & & 5 & 6.9 & 2 & 2.8 & 1 & 1.4 & 1 & 1.4 & $.019 *$ \\
\hline Ossiculum occipitomastoideum & & & & & 1 & 1.4 & 1 & 1.4 & & & .891 \\
\hline Os apicis & 1 & 1.4 & 3 & 4.2 & 4 & 5.6 & 2 & 2.8 & & & .981 \\
\hline Os epiptericum & & & 3 & 4.2 & 4 & 5.6 & & & & & .421 \\
\hline Os asterii & & & 3 & 4.2 & 1 & 1.4 & 1 & 1.4 & & & .560 \\
\hline Os inca & & & & & 1 & 1.4 & 1 & 1.4 & & & .891 \\
\hline Ossiculum bregmaticum & & & & & & & 1 & 1.4 & & & 616 \\
\hline Sutura metopica & & & 2 & 2.8 & & & & & & & .290 \\
\hline Sutura mendosa & & & 3 & 4.2 & 1 & 1.4 & & & & & .304 \\
\hline Torus occipitalis & 2 & 2.8 & 4 & 5.6 & 6 & 8.3 & 3 & 4.2 & & & .967 \\
\hline Linea nuchae suprema & 1 & 1.4 & 2 & 2.8 & 2 & 2.8 & 2 & 2.8 & & & .986 \\
\hline Condylus occipitalis partita & 1 & 1.4 & 1 & 1.4 & & & & & & & .499 \\
\hline Torus palatinus & 2 & 2.8 & 1 & 1.4 & 6 & 8.3 & 3 & 4.2 & & & .620 \\
\hline Torus maxillaris & 2 & 2.8 & & & & & & & & & $.013 *$ \\
\hline Torus mandibularis & & & & & 1 & 1.4 & 2 & 2.8 & & & .536 \\
\hline
\end{tabular}

$\mathrm{N}$, number of individuals; $\mathrm{y}$, years; ${ }^{*}, \mathrm{p}<.05$ 


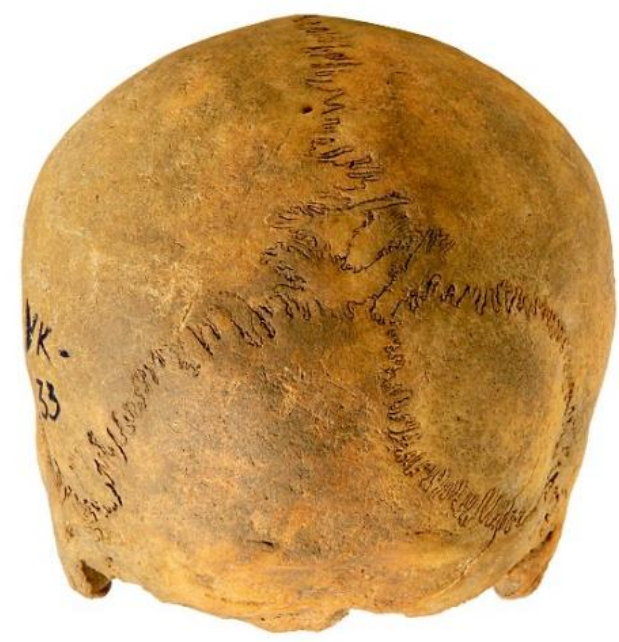

Fig. 3. Os incae laterale dextrum, associated with ossicula suturae sagittalis and torus occipitalis in a 50 to 55 -year-old male

\section{Vertebral column non-metric traits}

The prevalence of the vertebral column non-metric traits is presented in Table 4. Ponticulus atlantis posterior (complete in all cases) was encountered in 8 individuals $(11.1 \%)$. Only one case of ponticulus lateralis was observed. According to age, this trait was found more frequently in individuals aged 20-39 years. Spina bifida posterior atlantis lateralis (posterior arch cleft), an outcome of developmental deficiency of the posterior neural arch resulting in a bifid atlas, was observed in one female aged 45-50 years. The prevalence of FTP was high, $33.3 \%$ (24 individuals). In our sample FTP was frequently expressed as a trait affecting two or more adjacent cervical vertebra. Adjacent C5-6 vertebrae were most frequently affected. FTA was less frequent with a prevalence of $13.9 \%$ (10 individuals), mostly expressed as a trait affecting one cervical vertebra. FTA affected the atlas most frequently, followed by C2 (FT aperture which was observed posteriorly). Both FT traits were observed as associated traits in 7 individuals, in 5 of them affecting the same cervical vertebra (Figure 4). Asymmetric foramina transversaria were observed in 11 individuals, mostly at C6 and C7. In five cases FT asymmetry was associated with FTP affecting more adjacent cervical vertebra. Right foramina transversaria were generally observed as smaller. The prevalence of costa cervicalis was extremely high in our sample, $13.9 \%$ (10 individuals). Costa cervicalis was more frequently observed as bilateral trait (Table 5). Costa cervicalis was present as an associated trait with FTP in 5 and with FTA in 4 individuals (Figure 5). Two individuals showed costa cervicalis associated with both FTP and FTA. Bilateral costa cervicalis associated with both FTA and facies articularis bipartita in the atlas was encountered in one man aged 30-39 years (Figure 6). Two cervical blocks were observed in one man aged 50-59 years, at C2-3 and C5-6 level (Figure 7). In the thoracic spine hemivertebra Th3 and block vertebra Th10-11 were found, each trait in one individual. Costa lumbalis was observed in two males, in one case as an associated trait with partial lumbarization, in the other as associated trait with spina bifida occulta sacralis found as a small failure of fusion, a notch in the S1 spinous process. Five individuals showed lumbar spondylolysis (6.9\%), all of them aged 40-49 years (Table 6). Sacralization of the last lumbar vertebra was encountered in 4 individuals (5.6\%), in two of them as bilateral osseus fusion, and in the other two as a combined fusion. An associated combined fusion with bilateral costa cervicalis and foramen transversarium apertum C7 and with bilateral ponticulus posterior atlantis was observed in 30 to 35-year-old females (Figure 8). 
Table 4. Number and prevalence of vertebral non-metric traits according to gender in the medieval population sample from Vinichko kale necropolis

\begin{tabular}{lccccccc}
\multicolumn{1}{c}{ Vertebral traits } & \multicolumn{2}{c}{ Total } & \multicolumn{2}{c}{ Males } & \multicolumn{2}{c}{ Females } & \multirow{2}{*}{ p value } \\
\hline Facies articularis superior atlantis partita & 2 & 2.8 & 1 & 3.3 & 1 & 2.4 & 1.00 \\
Ponticulus atlantis lateralis & 1 & 1.4 & 1 & 3.3 & & & .417 \\
Ponticulus atlantis posterior & 8 & 11.1 & 4 & 13.3 & 4 & 9.5 & 1.00 \\
Spina bifida posterior atlantis lateralis & 1 & 1.4 & & & 1 & 2.4 & 1.00 \\
Foramen processus transversi partitum & 24 & 33.3 & 11 & 36.7 & 13 & 31 & .800 \\
Foramen processus transversi apertum & 10 & 13.9 & 4 & 13.3 & 6 & 14.3 & 1.00 \\
Facies articularis costalis C7 & 10 & 13.9 & 5 & 16.7 & 5 & 11.9 & .818 \\
Cervical block vertebra (C2-3/C5-6) & 1 & 1.4 & 1 & 3.3 & & & .417 \\
Thoracic hemivertebra (Th3) & 1 & 1.4 & & & 1 & 2.4 & 1.00 \\
Thoracic block vertebra (Th10-11) & 1 & 1.4 & 1 & 3.3 & & & .417 \\
Lumbar facies articularis costalis L1 & 2 & 2.8 & 2 & 6.7 & & & .170 \\
Lumbar spondylolysis (L4;L5) & 5 & 6.9 & 2 & 6.7 & 3 & 7.1 & 1.00 \\
Lumbalisation (S1) & 2 & 2.8 & 1 & 3.3 & 1 & 2.4 & 1.00 \\
Sacralisation (L5) & 4 & 5.6 & 1 & 3.3 & 3 & 7.1 & .636 \\
Spina bifida occulta sacralis & 1 & 1.4 & 1 & 3.3 & & & .417 \\
\hline N, number of individuals; ${ }^{*}$, p<.05 & & & & & & &
\end{tabular}

Table 5. Number and prevalence of vertebral non-metric traits according to laterality in the medieval population sample from Vinichko kale necropolis

\begin{tabular}{|c|c|c|c|c|c|c|c|c|c|}
\hline \multirow{2}{*}{ Vertebral traits } & \multicolumn{2}{|c|}{ Left } & \multicolumn{2}{|c|}{ Right } & \multicolumn{2}{|c|}{ Unilateral } & \multicolumn{2}{|c|}{ Bilateral } & \multirow{2}{*}{ p value } \\
\hline & $\mathbf{N}$ & $\%$ & $\mathbf{N}$ & $\%$ & $\mathbf{N}$ & $\%$ & $\mathbf{N}$ & $\%$ & \\
\hline Facies articularis atlantis partita & & & 2 & 2.8 & 2 & 2.8 & & & \\
\hline Ponticulus atlantis lateralis & & & & & & & 1 & 1.4 & \\
\hline Ponticulus atlantis posterior & 1 & 1.4 & 3 & 4.2 & 4 & 5.6 & 4 & 5.6 & 1.00 \\
\hline FTP $(\mathrm{C} 1 ; \mathrm{C} 5 ; \mathrm{C} 6 ; \mathrm{C} 7)$ & 6 & 8.3 & 4 & 5.6 & 10 & 13.9 & 6 & 8.3 & \\
\hline FTP (C5-6; C3-5;C4-6;C5-7) & 1 & 1.4 & & & $\begin{array}{c}1 \\
11\end{array}$ & 1.4 & $\begin{array}{c}7 \\
13\end{array}$ & 9.7 & .683 \\
\hline FTA $(\mathrm{C} 1 ; \mathrm{C} 2 ; \mathrm{C} 6 ; \mathrm{C} 7)$ & & & 2 & 2.8 & 2 & 2.8 & 6 & 8.3 & \\
\hline FTA (C1-2;C4-5) & & & 1 & 1.4 & $\begin{array}{l}1 \\
3\end{array}$ & & $\begin{array}{l}1 \\
7\end{array}$ & 1.4 & .527 \\
\hline Facies articularis costalis C7 & 2 & 2.8 & & & 2 & 2.8 & 8 & 11.1 & $.05^{*}$ \\
\hline Facies articularis costalis L1 & & & 1 & 1.4 & 1 & 1.4 & 1 & 1.4 & 1.00 \\
\hline Spondylolysis $(\mathrm{L} 4, \mathrm{~L} 5)$ & & & & & & & 5 & 6.9 & \\
\hline Sacralisation (L5) & & & & & & & 4 & 5.6 & \\
\hline
\end{tabular}

$\mathrm{N}$, number of individuals; $*, \mathrm{p}<.05$

Table 6. Number and prevalence of vertebral non-metric traits according to age in the medieval population sample from Vinichko kale necropolis

\begin{tabular}{|c|c|c|c|c|c|c|c|c|c|c|c|}
\hline \multirow{2}{*}{ Vertebral traits } & \multicolumn{2}{|c|}{$20-29 y$} & \multicolumn{2}{|c|}{$30-39 y$} & \multicolumn{2}{|c|}{$40-49 y$} & \multicolumn{2}{|c|}{$50-59 y$} & \multicolumn{2}{|c|}{$60-69 y$} & \multirow{2}{*}{ p value } \\
\hline & $\mathbf{N}$ & $\%$ & $\mathbf{N}$ & $\%$ & $\mathbf{N}$ & $\%$ & $\mathbf{N}$ & $\%$ & $\mathbf{N}$ & $\%$ & \\
\hline Facies articularis superior atlantis partita & 1 & 1.4 & 1 & 1.4 & & & & & & & .499 \\
\hline Ponticulus atlantis lateralis & & & & & 1 & 1.4 & & & & & .774 \\
\hline Ponticulus atlantis posterior & 1 & 1.4 & 6 & 8.3 & & & 1 & 1.4 & & & $.012 *$ \\
\hline Spina bifida posterior atlantis lateralis & & & & & 1 & 1.4 & & & & & .774 \\
\hline Foramen processus transversi partitum & 4 & 5.6 & 6 & 8.3 & 8 & 11.1 & 5 & 6.9 & 1 & 1.4 & .708 \\
\hline Foramen processus transversi apertum & 2 & 2.8 & 3 & 4.2 & 3 & 4.2 & 2 & 2.8 & & & .964 \\
\hline Facies articularis costalis C7 & 1 & 1.4 & 4 & 5.6 & 3 & 4.2 & 2 & 2.8 & & & .815 \\
\hline Block vertebra cervicalis & & & & & & & 1 & 1.4 & & & .470 \\
\hline Hemivertebra thoracalis & & & 1 & 1.4 & & & & & & & .551 \\
\hline Block vertebra thoracalis & & & & & 1 & 1.4 & & & & & .774 \\
\hline Facies articularis costalis L1 & & & 1 & 1.4 & & & 1 & 1.4 & & & .678 \\
\hline Lumbar spondylolysis & & & & & 5 & 6.9 & & & & & $.050 *$ \\
\hline Sacralisation L5 & 1 & 1.4 & 3 & 4.2 & & & & & & & .134 \\
\hline Lumbalisation S1 & & & & & 1 & 1.4 & 1 & 1.4 & & & .794 \\
\hline Spina bifida occulta sacralis & & & 1 & 1.4 & & & & & & & .551 \\
\hline
\end{tabular}

\footnotetext{
$\mathrm{N}$, number of individuals; $\mathrm{y}$, years; *, $\mathrm{p}<.05$
} 

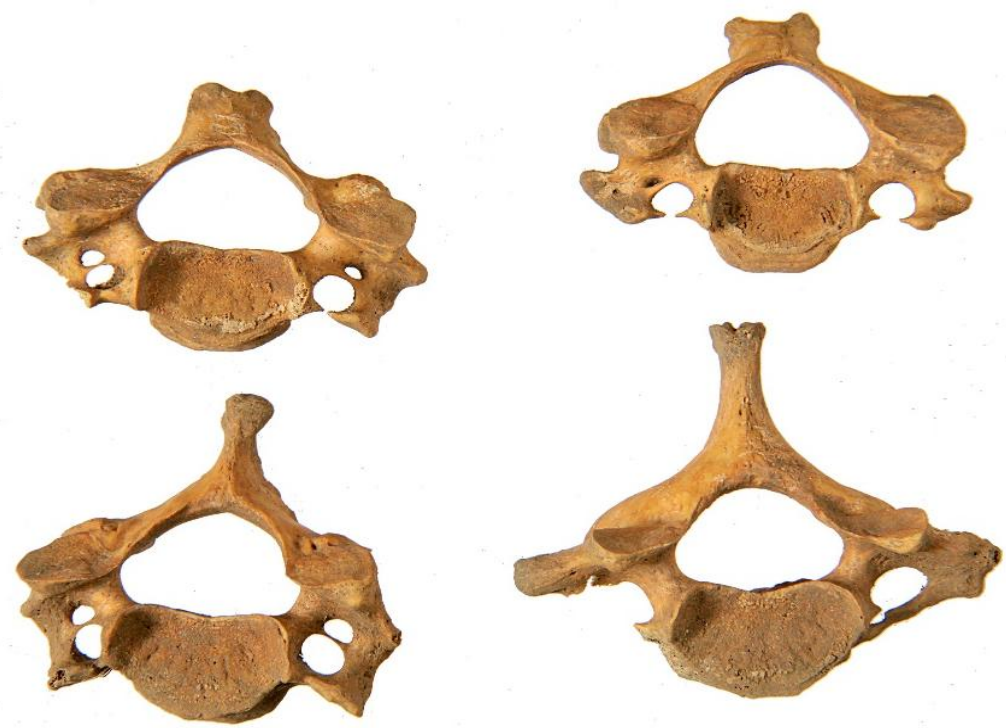

Fig. 4. Cervical vertebra of 20 to 25 -year-old female showing foramina transversaria partita, foramina transversaria aperta, and foramina transversaria asymmetrica
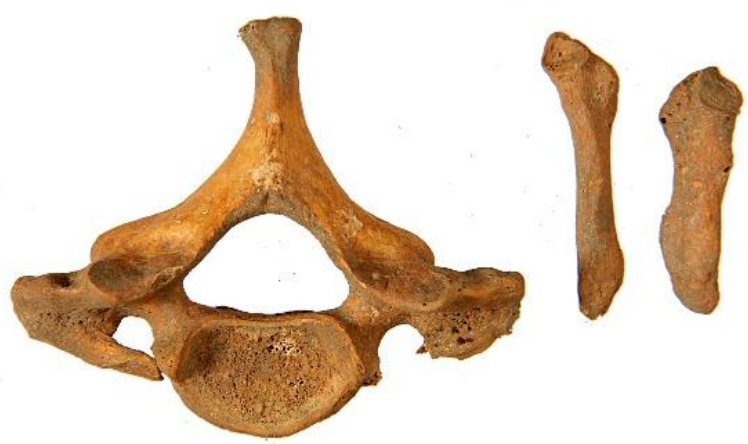

Fig. 5. Bilateral costa cervicalis and foramen transversarium apertum (FTA) in 30 to 35-year-old female

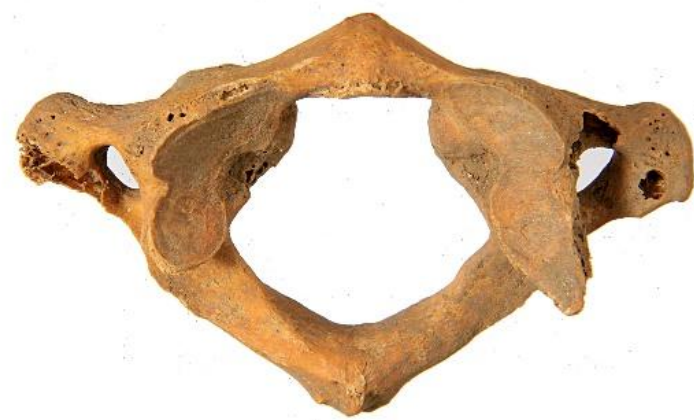

Fig. 6. Right facies articularis atlantis partita in 30 to 39 -year-old male 

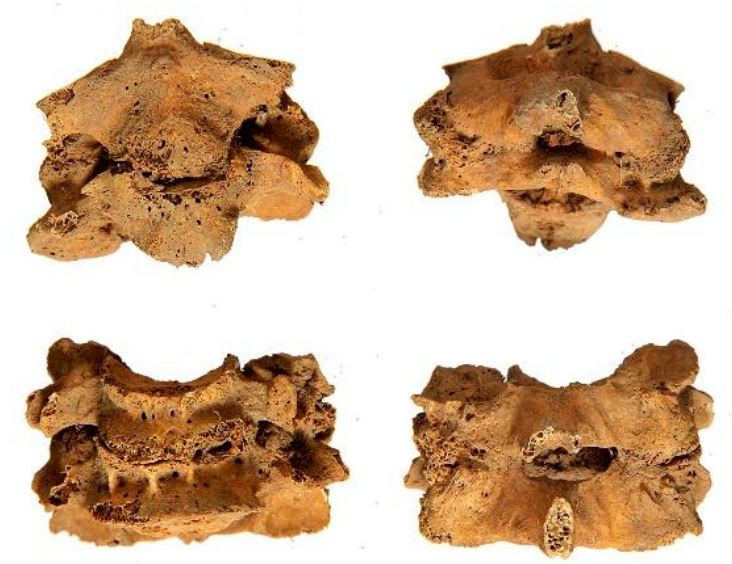

Fig. 7. Double cervical block C2/3 and C5/6 in 55 to 60-year-old male
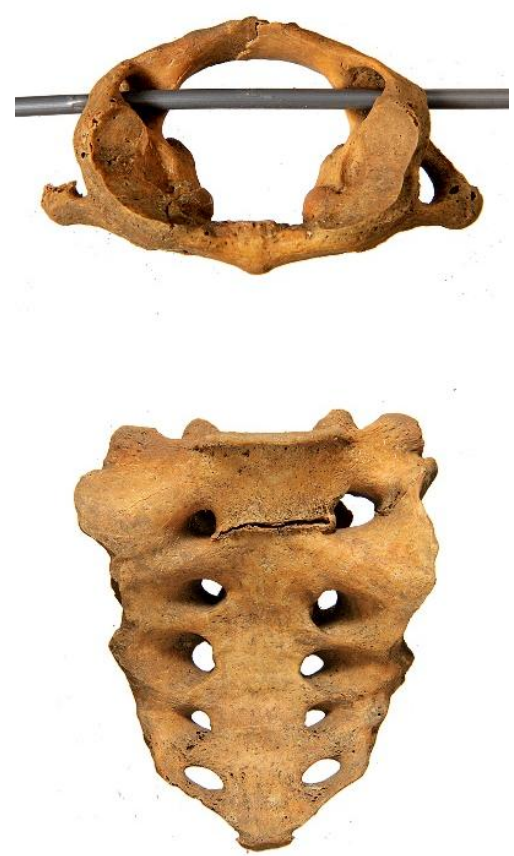

Fig. 8. Associated bilateral ponticulus posterior atlantis with sacralization (combined fusion) in 30 to 35 -year-old female

\section{Discussion}

The occurrence of cranial non-metric traits is probably associated with the development of the particular areas of the skull. Growth along an anteroposterior axis dominates in the postnatal craniofacial growth in humans. The neurocranium primarily exhibits growth along an anteroposterior axis at the basio-occipital synchondrosis and various cranial sutures [11]. Growth of the cranial vaults height occurs at squamosal sutures and at pteryion and asterion. During the period of growth separate centers may convert to Wormian bones. Wormian bones are formations associated with an insufficient rate of suture closure and are regarded as hypostatic traits [12]. The most common sites of Wormian bones occurrence in our study were lambdoid suture (55.6\%), pareital noch at the squamosal temporoparietal sutura $(12.5 \%)$, pteryon $(9.7 \%)$ and asteryon $(6.9 \%)$. The Wormian bones were most numerous within the posterior cranial sutures in our sample, similar to the findings of other authors [13]. The coronal and sagittal sutures ossicles showed less frequency, $4.2 \%$ and $5.6 \%$, respectively. Murlimanju et al. [14] reported a prevalence of $56.4 \%$ for Wormian bones within the lambdoid suture, $17.9 \%$ 
at the asterion and $11.5 \%$ at the pteryon. In Indian skulls the epipteric bone was reported as the second most common Wormian bone [15]. Preinterparietal bones were more numerous (13.9\%) compared to os incae, $(2.8 \%)$ in our medieval population. Os incae prevalence was similar to the results of a more extensive study [16] which reported a prevalence of $2.84 \%$. In medieval skull series, the reported os apicis prevalence was $10.8 \%$ [17]. The interparietal part of occipital squama undergoes membranous ossification from a variable number of ossification centers, thus occasional ossification centers independent from the surrounding bones lead to different occipital squama variations [8]. Torus occipitalis belongs to the supraoccipital, membranous part of the occipital squama and represents intermediate segment developing from the first pair of centers above the lower cartilaginous part. Torus occipitalis as a hyperostotic trait is more frequent in males, because of males' larger and more robust bones. In anthropoids torus occipitalis forms a distinct projection. Certain influence of environmental factors can impact Wormian bones formation in cranium with genetic susceptibility. Their incidence is high among Chinese population, perhaps because of the tradition of supine infant sleeping position that produces constant pressure on the occipital area [18].

The association between cervical spine and occipital bone traits is probably a consequence of strongly related development of the upper cervical vertebra with basiocciput and exocciput. Both non-metric traits, the irregularly shaped (bipartite) condyli occipitales and facies articularis atlantis bipartite, are manifestations of the occipital vertebra at the base of the crania. The reported incidence of such variants is about $0.1 \%$ to $0.5 \%$ for minor forms in general population [19]. Ponticulus posterior was encountered more frequently in our sample compared to ponticulus lateralis. The reported incidence of these traits is variable, between 1.8 and $3.8 \%$ for ponticulus lateralis and from 5\% to $35 \%$ for ponticulus posterior atlantis [20]. These structures are known to have an embryological origin and appear as features of nonhuman primates [21]. Ponticulus posterior atlantis was not related to advanced age in our investigation and therefore our findings do not support the thesis of ponticulus atlantis as a product of calcification or an ossification of the lateral segment of the posterior atlantooccipital membrane [22]. We found a high incidence of FTP mainly affecting C6 and C5, which was similar to the findings of many other authors who described FTP as a trait affecting 2 to 3 adjacent cervical vertebra. FTA was less frequent, most commonly affecting C1. Our results are in agreement with the results presented in a more extensive paleo-osteological study [23], where FTP was chiefly observed in C6 (with a right/left side prevalence of 35.7 and $44.4 \%$, respectively) and C5 vertebrae (23.6 and $23.9 \%$, right/left side, respectively), while FTA was mainly documented in $\mathrm{C} 1$ vertebrae $(8.4 \%)$. Our findings of FTP affecting adjacent cervical vertebra confirm the thesis that its origin may be developmental or related to the variations of the vertebral artery, that is duplication (segment of the primitive dorsal aorta with 2 intersegmental arteries) and fenestration (failure of a controlled regression of intersegmental arteries). It is considered that posterior smaller FT encloses a branch of vertebral artery along with a vein or in some cases double vertebral artery. Only 74 cases of fenestration and 22 cases of duplication of the vertebral artery are reported in the literature [24]. Cervical ribs as a manifestation of cranial shifting have been reported to occur in less than $1 \%$ of the population [25], in contrary to our medieval population with extremely high overall frequency of cervical ribs. Some authors reported $\mathrm{C} 2-\mathrm{C} 3$ as a common site of block vertebra with an incidence of $0.4 \%$ to $0.7 \%$ with no sex predilection [26]. Two cervical blocks affecting $\mathrm{C} 2 /$ $\mathrm{C} 3$ and $\mathrm{C} 5 / \mathrm{C} 6$ in one male skeleton were found in our population. The prevalence of lumbosacral transitional vertebra was higher in our medieval population compared to the transitional thoracolumbar segment. The reported prevalence of transitional states is between 4 and $30 \%$ for transitional lumbosacral vertebra [27] and $4.1 \%$ for transitional thoracolumbar segments [28]. In our sample spondylolysis primarly involved L5 bilaterally in individuals aged 40-49 years, hence our results support the thesis of spondylolysis as a consequence of 
hereditary predisposition to the pars interarticularis defects and influence of biomechanical stress factors. The incidence of spondylolysis is estimated to be about $6-8 \%$ of the population, with higher incidence found in individuals engaged in sport activities [29]. C1 clefting and spina bifida occulta sacralis, an asymptomatic form of spinal dysraphism, both involve agenesis of the neural arch. Regarding the origin of spinal dysraphism, the occurrence seems to be dependent on both environmental and genetic factors in addition to the variability in the timing of fusion of the vertebra. Cranial and caudal shifting are related to genetic influence, thus traits connected with caudal or cranial shifting were associated in our population. Cervical ribs were associated with traits that are manifestation of cranial shifting like bipartite articular atlas surface, i.e. atlas variant that presents occipital vertebra or proatlas manifestation and sacralisation of the last lumbar vertebra. Lumbar ribs were associated with lumbalization of the sacrum, as a result of caudal shifting of the vertebral column. The limitation of our study is the sample size; a larger number of individuals from the same population will provide stronger statistical support. Evaluating traits that are rare (found in one or two individuals) with a large number of absent cases could potentially skew the results.

Kohn et al. [30] reported that non-metric traits are often inherited in groups that are encoded for by the same set of genes. There is a complex relationship between multiple genes coding for the traits and the confounding factors. Multiple factors confound the hereditability of each non-metric trait and have effect on its expression like sexual dimorphism, age, nutrition, disease, habitat and intertrait correlations [31].

In conclusion, most of the axial skeleton non-metric traits evaluated in our medieval population sample showed frequencies similar to those reported in contemporary and past populations, except for occipital bone traits (os apicis and torus occipitalis) and cervical spine traits (FTP, FTA and cervical ribs). Findings of population specific non-metric traits can be useful in determining genetic relatedness and can provide additional knowledge about the skeletal growth and development in general.

\section{Acknowledgement}

We would like to express our gratitude to the employees of the Archeological Museum of the R. North Macedonia for their generous help, kindness and assistance with the skeletal collections.

Conflict of interest statement. None declared.

\section{References}

1. Barnes E. Developmental Defects of the Axial Skeleton in Paleopathology.1994; University Press of Colorado.

2. Saunders SR. Nonmetric skeletal variation. In: Reconstruction of life from the skeleton. 1989; Alan R. Liss: New York; 1989; p: 95-21.

3. Saunders SR, Rainey DL. Nonmetric Trait Variation in the Skeleton: Abnormalities, Anomalies, and Atavisms. In: Katzenberg AM and SR Saunders, editors. Biological Anthropology of the Human Skeleton, second ed. Hoboken, NJ: Wiley-Liss 2008; p. 533560.

4. Edwards J. An Investigation of Nonmetric Discontinuous Trait Variation of the Atlas in Ancient Egyptian Population Samples from the Dakhleh Oasis, Egypt. Honour's thesis 2005; Department of Anthropology. Lakehead University.

5. Balabanov K. Vinica Fortress. Macedonian treasures. Skopje: Matica 2011; p: 56-69.

6. Veljanovska F. Anthropological features of inhabitants of Macedonia from the Neolithic to the Middle Ages. Skopje: RZZS; 2000 (in Macedonian).

7. Buikstra JE, Ubelaker DH. Standards for Data Collections from Human Skeletal Remains. Arkansas: Arkansas Archaeological Survey 1994. 
8. Matsumura G, Uschiumi T, Kida K, Ichikawa R, Kodama G. Developmental studies on the interparietal part of the human occipital squama. J Anat 1993; 182: 197-204.

9. Srivastava HC. Ossification of the membranous portion of the squamous part of the occipital bone in man. J Anat 1992; 180: 219-24.

10. Finnegan M. Nonmetric Variation of the Infracranial Skeleton. J Anat 1978; 125(1): 23-37.

11. Enlow DH. Facial growth. Philadelphia: W.B. Saunders; 1990.

12. Barberini F, Bruner E, Cartolari R, Franchito G, Heyn R, Ricci F, et al. An unusuallywide human bregmatic Wormian bone: anatomy, tomographic description and possible significance. Surg Radiol Anat 2008; 30(8):683-7. DOI: 10.1007/s00276-008-0371-0.

13. Sanchez-Lara PA, Graham Junior JM, Hing AV, Lee J, Cunningham M. The morphogenesis of Wormian bones: a study of craniosynostosis and purposeful cranial deformation. Am J Med Genet 2007; 143A(24):3243-51. DOI: 10.1002/ajmg.a.32073.

14. Murlimanju BV, Prabhu LV, Ashraf CM, Kumar CG, Rai R, Maheshwari C. Morphological and topographical study of Wormian bones in cadaver dry skulls. $J$ Morphol Sci 2011; 28(3): 176-9.

15. Nayak S. Presence of Wormian bone at bregma and paired frontal bone in an Indian skull. Neuroanatomy 2006; 5: 42-3.

16. Kadanoff D, Mustafov S. The human skull in medico-anthropological aspect, form, dimensions, variability. Sofia: Prof. Marin Drinov Academic Publishing House; 1984 (in Bulgarian).

17. Nikolova S, Toneva D, Yordanov Y, Lazarov N. Variations in the squamous part of the occipital bone in medieval and contemporary cranial series from Bulgaria. Folia Morphol 2014; 73(4): 429--38. DOI:10.5603/FM.2014.0055

18. Graham JM, Kreutzman J, Earl D, Halberg A, Samayoa C, Guo X. Deformational brachiocephaly in supine sleeping infants. $J$ Pediatr 2005; 146:253-7. DOI: 10.1016/j. jpeds.2004.10.017.

19. Prescher A, Brors D, Adam G. Anatomic and Radiologic Appearance of Several Variants of the Craniocervical Junction. Skull Base Surg 1996; 6(2): 83-94.

20. Schilling J, Schilling A, Galdames IS. Ponticulus posticus on the Posterior Arch of Atlas, Prevalence Analysis in Asymptomatic Patients. Int J Morphol 2010; 28(1): 317-22.

21. Le Minor JM, Trost O. Bony ponticles of the atlas (C1) over the groove of the vertebral artery in humans and primates: polymorphism and evolutionary trends. Am J Phys Anthropol 2004; 125: 16-29. DOI:10.1002/ajpa.10270.

22. Krishnamurthy A, Nayak SR, Khan S, Prabhu LV, Ramanathan LA, Ganesh Kumar $\mathrm{C}$, et al. Arcuate foramen of atlas: incidence, phylogenetic and clinical significance. Rom J Morphol Embryol 2007; 48: 263-6.

23. Travan L, Saccheri P, Gregoraci G, Mardegan C, Crivellato E. Normal anatomy and anatomic variants of vascular foramens in the cervical vertebrae: a paleo-osteological study and review of the literature. Anat Sci Int. 2015; 90(4):308-23. DOI: 10.1007/s12565014-0270-x.

24. Sim E, Vaccaro AR, Berzlanovich A, Thaler H, Ullrich CG. Fenestration of the extracranial vertebral artery: Review of the literature. Spine 2001; 26: 139-42.

25. Sanders RJ, Hammond SL. Management of cervical ribs and anomalous first ribs causing neurogenic thoracic outlet syndrome. J Vasc Surg 2002; 36(1): 51-6.

26. Soni P, Sharma V, Sengupta J. Cervical vertebrae anomalies-incidental findings on lateral cephalograms. Angle Orthod 2008; 78: 176-80. DOI:10.2319/091306-370.1.

27. Konin GP, Walz DM. Lumbosacral transitional vertebrae: classification, imaging findings, and clinical relevance. Am J Neuroradiol 2010; 31: 1778-86. DOI:10.3174/ajnr.A2036. 
28. Carrino JA, Campbell PD Jr, Lin DC, Morrison WB, Schweitzer ME, Flanders AE, et al. Effect of spinal segment variants on numbering vertebral levels at lumbar MR imaging. Radiology 2011; 259: 196-202. DOI:10.1148/radiol.11081511.

29. Leone A, Cianfoni A, Cerase A, Magarelli N, Bonomo L. Lumbar Spondylolysis: A Review. Skeletal Radiol 2011; 40(6): 683-700. DOI:10.1007/s00256-01-00942-0.

30. Khon LAP. The role of genetics in craniofacial morphology and growth. Ann Rev Anthropol 1991; 20: 261-78. DOI: 10.1146/annurev.an.20.100191.001401.

31. Hlusko LJ. Integrating genotype and phenotype in hominid paleontology. Natl Acad Sci U S A. 2004; 101(9): 2653-7. DOI: 10.1073/pnas.0307678101. 